\title{
Brand Image, Kualitas Pelayanan Dan Kepuasan Konsumen Di Dalam Pengaruhnya Terhadap Minat Ulang Penggunaan Aplikasi Dana
}

Submitted Date :

27 Oktober 2020

Accepted Date :

20 April 2021
Lilik Indrawati

Universitas Katolik Darma Cendika lilik.indrawati@ukdc.ac.id

Marcell Mathias Pattinama Universitas Katolik Darma Cendika

\section{Suggested Citation:}

Alawi, N.M., Asih, V.S., \& Sobana, D.H. (2020). Pengaruh Literasi Keuangan Dan Inklusi Mahasiswa Uin Sunan Gunung Djati Bandung Terhadap Penggunaan Sistem Financial Technology. Jurnal MAPS (Manajemen Perbankan Syariah), 4(1):36-44

\section{Abstract:}

The purpose of this study was to determine the effect of brand image, service quality and customer satisfaction on re-interest in using the Dana application. The population in this study were students of Darma Cendika Catholic University, Widya Mandala Catholic University Surabaya and St. Vincetius Paolo University (RKZ). The sample is 75 respondents, with the consideration that this number can represent the research sample. This research method is quantitative with multiple regression analysis, the data entered is processed with SPSS version 20. The results of this study indicate that brand image and service quality do not affect re-interest using Dana application for students in Surabaya, and consumer satisfaction has a significant effect on re-interest in using the Dana application to students in Surabaya.

Keywords : Brand Image, Service Quality, Customer Satisfaction, Re-Interest, Dana Application

\section{Abstrak:}

Tujuan penelitian ini adalah untuk mengetahui pengaruh brand image, kualitas pelayanan dan kepuasan konsumen terhadap minat ulang menggunakan aplikasi Dana. Populasi dalam penelitian ini adalah mahasiswa Universitas Katolik Darma Cendika, Universitas Katolik Widya Mandala Surabaya dan Universitas St Vincetius Paolo (RKZ). Sampelnya sebanyak 75 responden, dengan pertimbangan bahwa jumlah tersebut sudah dapat mewakili sebagai sampel penelitian. Metode penelitian ini adalah kuantitatif dengan analisa regresi berganda, data yang masuk diolah dengan SPSS versi 20. Hasil penelitian ini menunjukan bahwa brand image dan kualitas pelayanan tidak berpengaruh terhadap peminat ulang menggunakan aplikasi Dana pada mahasiswa di Surabaya, dan kepuasan konsumen berpengaruh signifikan terhadap minat ulang penggunaan aplikasi Dana pada mahasiswa di Surabaya.

Kata Kunci: Brand Image, Kualitas Pelayanan, Kepuasan Konsumen, Minat Ulang, Aplikasi Dana

JEL Classification: M31 


\section{Latar Belakang}

Pada perkembangan jaman yang lebih modern sistem pembayaran dalam transaksi ekonomi mengalami kemajuan yang sangat pesat menurut data "Bank Indonesia" seperti tabel 1 mulai tahun 2013 - Februari 2020 dimana perkembangan teknologi yang semakin canggih. Kemajuan teknologi dalam sistem berbagai pembayaran telah menggantikan peranan uang tunai (currency) yang dikenal luas oleh masyarakat sebagai alat pembayaran ke dalam bentuk pembayaran non tunai yang lebih efektif dan efisien. Hal ini didukung dengan semakin banyaknya Perusahaan ataupun pusat perbelanjaan di Indonesia yang menerima transaksi pembayaran dengan menggunakan sistem pembayaran non tunai atau yang dimana lebih dikenal dengan emoney. Transaksi tersebut lebih cepat, lebih aman, lebih nyaman, lebih mudah dan lebih efesien dalam bertransaksi, sehingga menjadi alasan masyarakat Indonesia memiliki respon yang besar terhadap sistem pembayaran non tunai dan sistem pembayaran non tunai ini telah dikembangkan oleh pihak Bank maupun non Bank sebagai Lembaga penyelenggara sistem pembayaran di Indonesia. Bank Indonesia pun mendorong gerakan less cash society (LCS) atau penggunaan uang elektronik sebagai pengganti pembayaran tunai di Indonesia. Walaupun Data BI menyebutkan penguna e-money terkonsentrasi di Kota-kota besar di Pulau Jawa, Sumatera dan sebagian Sulawesi serta pemakaiannya masih sekitar sektor transportasi, seperti toll, pompa bensin, parkir dan transaksi di mini market, namun pengguna Uang Elektronik semakin meningkat dari tahun ke tahun:

Tabel 1. Peredaran Uang ElektronikMulai dari Tahun 2013 - Februari 2020

\begin{tabular}{lc}
\hline \multicolumn{1}{c}{ Periode } & Jumlah Instrumen \\
\hline Tahun 2013 & $36,225,373$ \\
Tahun 2014 & $35,738,233$ \\
Tahun 2015 & $34,314,795$ \\
Tahun 2016 & $51,204,580$ \\
Tahun 2017 & $90,003,848$ \\
Tahun 2018 & $167,205,578$ \\
Tahun 2019 & $292,299,320$ \\
Tahun 2019 Maret & $199,174,153$ \\
Tahun 2019 April & $197,413,945$ \\
Tahun 2019 Mei & $198,790,786$ \\
Tahun 2019 Juni & $209,891,847$ \\
Tahun 2019 Juli & $232,348,971$ \\
Tahun 2019 Agustus & $250,477,938$ \\
Tahun 2019 September & $257,078,749$ \\
Tahun 2019 Oktober & $269,340,218$ \\
Tahun 2019 November & $277,925,012$ \\
Tahun 2019 Desember & $292,299,320$ \\
Tahun 2020 Januari & $313,785,298$ \\
Tahun 2020 Februari & $319,294,014$ \\
\hline
\end{tabular}

Sumber : Bank Indonesia 2013 - Februari 2020

Berdasarkan dari tabel 1 dijelaskan bahwa perkembangan Uang Elektronik atau e-money mengalami peningkatan yang pesat dari tahun ke tahun sehingga membuat gaya konsumtif masyarakat saat ini mulai menunjukkan perbedaan dengan memilih tingkat kemudahan, keamanan dan kecepatan yang makin efektif.

Pada momen ini Perusahaan uang elektronik, salah satunya PT Espay Debit Indonesia Koe atau sering dikenal dengan aplikasi Uang Elektronik adalah Perusahaan yang menghadirkan produk e-money yaitu DANA atau sering disebut Dompet Digital, salah satu alternatif produk dompet digital di tengah-tengah masyarakat Indonesia. Prinsip pembuatan aplikasi seperti yang disampaikan CEO DANA Vincent Henry Iswaratioso adalah menyediakan fasilitas transaksi keuangan non tunai - non kartu, baik secara online maupun offline dengan lebih cepat, praktis dan aman, hanya dengan menggunakan suatu aplikasi yang diunduh pada telepon pintar penggunanya. DANA menargetkan dua kelompok pengguna utama yaitu perorangan dan pelaku bisnis. Pengguna perorangan, DANA hadir dengan fasilitas pembayaran transaksi baik secara online dan menjamin segala privasi dan keamanan bagi para pemakai aplikasi. Penggunaan alat pembayaran uang elektronik ini secara perlahan telah merubah pola hidup dan gaya transaksi masyarakat mulai dari pembayaran non tunai/cash menjadi lebih instant transfer atau debit pada masyarakat dalam melakukan transaksi ekonomi. Kini penggunaan 
kartu pembayaran jenis tersebut menjadi alternatif alat transaksi pada masyarakat selain uang. Menurut Menurut Kotller dan Keller (2013) bahwa brand image ialah sebagai persepsi dimana sebuah brand atau merek akan direfleksikan oleh Perusahaan guna membuat brand atau merek yang terdapat dalam benak para konsumen dan bisa dimengerti dengan mudah. Menurut Roslina (2010), mendefinisikan bahwa brand image merupakan petunjuk yang akan digunakan oleh konsumen guna untuk mengevaluasi atau menentukan pilihan suatu produk dimana konsumen ingin menggunakannya tetapi tidak memiliki pengetahuan yang cukup tentang produk tersebut. Sedangkan Menurut Rangkuti (2012), brand image adalah sekumpulan asosiasi dari merek yang melekat di benak konsumen sehingga pada pola pandang konsumen dapat mengerti. akan citra merek suatu produk tersebut.

Menurut Tjiptono (2014) bahwa kualitas pelayanan ialah suatu perusahaan penyedia jasa atau barang yang berfokus pada upaya pemenuhan suatu kebutuhan dan keinginan dari konsumen serta ketepatan penyampaian mengenai suatu produk tersebut sehingga perusahaan dapat mengimbangi harapan konsumen. MenurutTjiptono (2008) dalam Sunyoto (2012) bahwa kualitas pelayanan dalam industri jasa, pelayanan adalah suatu bentuk penyajian produk atau jasa yang harus sesuai ukuran yang berlaku dan penyampaian produk atau jasa setidaknya harus sama dengan yang diingkan oleh konsumen. Menurut Wyock dalam Tjiptono (2014: 268) kualitas pelayanan merupakan tingkat keunggulan dari suatu. perusahaan atau nilai (excellent) yang diharapkan.oleh konsumen dan seluruh pengendalian. produknya dapat memenuhi kebutuhan konsumen.

Menurut Tjiptono (2014), bahwa kepuasan konsumen adalah tingkat perasaan senang atau kecewa dari pelanggan setelah membandingkan antara jasa atau barang yang telah konsumen terima dengan harapan saat belum menerima produk yang konsumen inginkan tersebut. Menurut Kotler dan Keller (2007) dalam Daryanto dan Setiyabudi (2014) bahwa Kepuasan Konsumen adalah perasaan emosional yang muncul secara tiba-tiba dalam benak konsumen setelah. membandingkan kinerja (hasil) suatu produk. yang dipikirkan. terhadap suatu kinerja dengan harapan yang diinginkan.

Minat ulang menurut Thamrin dan Francis (2012), merupakan minat pembelian yang didasarkan pada konsumen atas pengalaman pembelian yang telah dilakukan oleh konsumen pada masa lalu, guna dapat menjadi pertimbangan dalam menggunakan produk tersebut secara ulang. Minat Ulang timbul ketika setelah adanya proses evaluasi yang dialami konsumen sehingga menjadi pertimbangan saat memutuskan minat ulang (Kotler, 2014).

Berdasarkan penelitian pendahuluan, peneliti mewawancarai 15 pengguna dana di beberapa mall seperti di Galaxi mall (5 pengguna), Tunjungan Plaza ( 5 pengguna), East Coast (3 pengguna) dan Surabaya Town Square (2 pengguna) yang diperoleh 12 pengguna aplikasi dana (80\%) adalah mahasiswa, sisanya adalah karyawan, dan wiraswasta. Mereka memiliki beberapa aplikasi, salah satunya adalah aplikasi Dana.

Bagi mahasiswa, kehadiran fintech yang memberikan kemudahan transaksi dan banyak reward merupakan hal baru dan menyenangkan untuk diterapkan dalam kehidupan sehari-hari (Pambudi, 2019). Hasil penelitian (Alawi et al., 2020) bahwa minat mahasiswa terhadap penggunaan financial technology saat ini dan kedepannya sangatlah baik. Dimana terdapat pengaruh yang positif dan signifikan antara self-efficacy terhadap perceived ease of use alat pembayaran dompet digital pada mahasiswa. Hasil penelitian (Febrilia et al., 2020).

Perusahaan fintech payment di Indonesia, salah satunya adalah DANA. Persaingan bisnis yang ketat sehingga mengharuskan perusahaan untuk merancang suatu strategi pemasaran yang didasari dengan riset perilaku konsumen (Safira et al., 2019). Bisnis fintech di Indonesia saat ini dikuasai produk-produk milik perusahaan tekfin seperti Go-Pay, OVO, dan DANA. Tercatat 73\% responden mengaku memakai layanan OVO dan 71\% memiliki Go-Pay, sedangkan pengguna DANA baru 1\% (Immawati \& Dadang, 2019).

Untuk mengetahui perilaku mahasiswa Katolik yang ada di Surabaya sebagai konsumen pengguna aplikasi DANA perlu dilakukan survei dan penelitian keputusan mahasiswa terhadap minat ulang penggunaan aplikasi DANA dengan mengetahui pengaruh brand image, kualitas pelayanan dan kepuasan konsumen.

\section{Metode Penelitian}

Pendeketan penelitian ini menggunakan metode kuantitatif. Variabel independen dalam penelitian ini adalah brand image (X1), Kualitas Pelayanan(X2) dan Kepuasan Konsumen (X3). Variabel dependen, atau variabel terikat di dalam penelitian ini adalah Minat Ulang (Y). Metode pengambilan sampel yang digunakan dalam penelitian ini adalah non-probability sampling dengan purposive sampling. Populasi dalam penelitian ini mahasiswa Universitas Katolika Darma Cendika, Universitas Katolik Widya Mandala dan Universitas St Paolo 
Vincetius RKZ. Kreteria sampel dalam penelitian ini pertama adalah mahasiswa berstatus aktif, kedua mahasiswa memakai Aplikasi DANA. Dari kreteria sampel tersebut diperoleh 75 responden. Teknik analisis data yang digunakan di dalam penelitian ini adalah regresi linier berganda.

Hasil

Sebelum melakukan uji hipotesis, maka instrument penelitian diuji terlebih dahulu dengan menggunakan uji validitas dan reliabilitas, Setelah itu, dilakukan asumsi klasik yang dilanjutkan dengan regresi linear berganda, koefisien determinan dan uji t.

Uji validitas digunakan untuk menguji valid tidaknya item dari pernyataan pada tiap variabel penelitian. Berikut hasil penelitian terhadap responden dapat dilihat di tabel 2 sebagai berikut :

Tabel 2. Hasil Uji Validitas Untuk Semua Variabel

\begin{tabular}{llc}
\hline Variabel & Pernyataan & r-hitung \\
\hline Brand Image(X1) & X1.1= Aplikasi Dana mudah diingat, & 0,681 \\
& X1.2= Aplikasi Dana mudah dikenal, & 0,818 \\
Kualitas Pelayanan(X2) & 0,534 \\
& X1.3= Aplikasi Dana memiliki reputasi yang baik & 0,609 \\
& X2.1= pelayanan yang tepat dan akurat & 0,674 \\
& X2.3= =memberikan respon yang optimal & 0,729 \\
& X2.4= memberikan bonus & 0,729 \\
X2.5= daya tarik tersendiri & 0,758 \\
Kepuasan konsumen & X3) & 0,715 \\
& X3.1= merasa puas ketika menggunakan Aplikasi Dana & 0,743 \\
& X3.3= melalu tertarik dengan fitur & 0,855 \\
Minat Ulang (Y) & X3.4= merasa terpenuhi Ketika menggunakan Aplikasi Dana & 0,878 \\
& Y1.1= menjadi pilihan utama. & 0,882 \\
& Y1.2 = selalu tertarik dengan promo dari Dana & 0,746 \\
Y1.3= Keinginan selalu terpenuhi dan sesuai kenyataan . & 0,843 \\
& Y1.4= tidak pernah ragu dengan pelayanan yang diberikan & 0,756 \\
\hline
\end{tabular}

Sumber: Data Sekunder Diolah (2020)

Berdasarkan pada tabel 2 dapat diketahui bahwa nilai $r$ - hitung yang ada pada semua item pernyataan pada semua variabel lebih besar $\geq$ dari pada nilai $r$ tabel $(0.2272)$, dengan demikian dapat disimpulkan bahwa semua item dalam pernyataan pada kuisioner penelitian kali ini dapat dikatakan valid.

Berikut hasil penelitian uji reliabilitas dengan menggunaakan test retest, yaitu melakukan perhitungan total dengan score kuesioner sebaran ulang, dengan mencari korelasinya dengan metode yang sama dengan uji validitas atau dengan menggunakan excel, dapat dilihat hasil test retest di tabel 3 sebagai berikut :

Tabel 3. Hasil Uji Reliabilitas

\begin{tabular}{lc}
\hline Variabel & Cronbach Alpha Ulang \\
\hline Brand Image (X1) & 0,867779 \\
Kualitas Pelayanan (X2) & 0,739557 \\
Kepuasan Konsumen (X3) & 0,840744 \\
Minat Ulang (Y) & 0,840432 \\
\hline
\end{tabular}

Sumber: Data Sekunder Diolah (2020)

Uji reliabilitas digunakan untuk menguji tingkat kekonsistenan kuesioner. Adapun uji reliabilitas yang digunakan pada penelitian ini yaitu teknik konsistensi internal dengan teknik alpha cronbach. Suatu kuesioner dikatakan reliabel jika nilai alpha cronbach's > 0,60. (Kurniawan, 2011; 51). Dari tabel 3 bahwa variabel Brand Image (X1), Kualitas Pelayanan (X2), Kepuasan Konsumen (X3) dan Minat Ulang (Y) memiliki nilai alpha cronbach > 0,6, dapat ditarik kesimpulan bahwa seluruh variabel yang dipakai dalam penelitian ini reliabel. 
Tabel 4. Hasil Uji Regresi Linear Berganda

\begin{tabular}{|c|c|c|c|c|c|c|c|c|}
\hline \multicolumn{9}{|c|}{ Coefficients ${ }^{\mathrm{a}}$} \\
\hline \multirow{2}{*}{\multicolumn{2}{|c|}{ Model }} & \multicolumn{2}{|c|}{$\begin{array}{l}\text { Unstandardized } \\
\text { Coefficients }\end{array}$} & \multirow{2}{*}{$\begin{array}{c}\text { Standardized } \\
\text { Coefficients } \\
\text { Beta }\end{array}$} & \multirow[b]{2}{*}{$t$} & \multirow[b]{2}{*}{ Sig. } & \multicolumn{2}{|c|}{ Collinearity Statistics } \\
\hline & & B & $\begin{array}{l}\text { Std. } \\
\text { Error }\end{array}$ & & & & Tolerance & VIF \\
\hline & (Constant) & 2.462 & 2.395 & & 1.028 & .307 & & \\
\hline 4 & Brand Image & .039 & .215 & .017 & .184 & .855 & .682 & 1.466 \\
\hline 1 & Kualitas Pelayanan & .038 & .146 & .030 & .263 & .794 & .457 & 2.191 \\
\hline & Kepuasan Konsumen & .776 & .120 & .731 & 6.449 & .000 & .460 & 2.172 \\
\hline
\end{tabular}

Sumber: Data Sekunder Diolah (2020)

Penelitian ini telah memenuhi uji asumsi klasik, yaitu uji normalitas, multikolinearitas dan uji heteroskedastisitas. Dari hasil uji regresi linerar berganda, diperoleh bahwa variabel Brand image dan kualitas pelayanan berpengaruh tidak signifikan dengan hasil t hitung dari kedua variabel tersebut $<\mathrm{t}$ tabel yaitu 1,99394 dengan tingkat signifikasi $>0,05$ artinya $\mathrm{H}_{0}$ diterima dan $\mathrm{H}_{1}$ ditolak, sehingga brand image dan kualitas pelayanan berpengaruh tidak signifikan terhadap minat ulang penggunaan aplikasi DANA. Uji t pada Kepuasan Konsumen (X3) menghasilkan thitung $>\mathrm{t}$ tabel 1,99394 dengan tingkat signifikasi $0.000<0,05$ artinya $\mathrm{H}_{0}$ ditolak dan $\mathrm{H}_{1}$ diterima, sehingga pada variabel ini diketahui bahwa Kepuasan Konsumen berpengaruh signifikan terhadap minat ulang penggunaan aplikasi DANA pada mahasiswa di Surabaya. Selanjutnya, nerdasarkan hasil penelitian diketahui nilai $R$ Square sebesar 0,580 dengan hasil adjusted $R$ square sebesar 0,562 atau $56,2 \%$ yang artinya, variabel independent yaitu Brand Image (X1), Kualitas Pelayanan (X2) dan Kepuasan Konsumen (X3) berkontribusi cukup terhadap variabel dependent yaitu Minat Ulang $(Y)$.

\section{Kesimpulan}

Dari hasil penelitian ini dapat disimpulkan bahwa Brand Image dan kulitas pelayanan berpengaruh tidak signifikan terhadap penggunaan minat ulang penggunaan aplikasi Dana. Selanjutnya, kepuasan konsumen berpengaruh signifikan terhadap Minat Ulang penggunaan aplikasi Dana pada Mahasiswa di Surabaya. Mahasiswa menggunakan aplikasi Dana tidak melihat brand image dan kualitas pelayanan aplikasi Dana, bagi mahasiswa brand image dan kualitas pelayanan aplikasi Dana sama dengan aplikasi fintech lainnya. Minat ulang penggunaan aplikasi Dana bagi mahasiswa apabila aplikasi Dana memberi pelayanan yang akurat, pelayanan customer service yang baik, jaminan keamanan saat bertransaksi, dan pemberian bonus kepada pelanggan tetap dan Dana memberikan pelayanan fitur yang dapat menarik dibanding dengan aplikasi lainnya. Mahasiswa akan merasa puas dari segala jenis aspek kebutuhannya mulai dari saat perasaan menggunakan aplikasi Dana, tertarik akan fitur pada aplikasi Dana dan merekomendasikan Dana ke orang lain sehingga mereka juga menggunakan aplikasi dana guna terpenuhi kebutuhan sehari-harinya.

Hasil penelitian ini belum mampu untuk mengeneralisasi di obyek penelitian lainnya, hal karena jumlah sampel yang dipergunakan dalam penelitian ini terbatas sedangkan aplikasi Dana dipakai hampir diseluruh Indonesia, populasi dan sampel hanya pada mahasiswa yang kuliah di Universitas Katolik di Surabaya dan hasil penelitian menunjukkan bahwa variabel brand image, kualitas pelayanan berpengaruh tidak ignifikan minat ulang penggunaan aplikasi Dana. Saran untuk para penelitian berikutnya yang menggunakan variabel minat minat ulang penggunaan aplikasi dana bisa meningkatkan populasi dan sampel, serta variabel lainnya seperti perilaku konsumen, tingkat keandalan fitur dan faktor sosial lainnya.

\section{References}

Alawi, N.M., Asih, V.S., \& Sobana, D.H. (2020). Pengaruh Literasi Keuangan Dan Inklusi Mahasiswa Uin Sunan Gunung Djati Bandung Terhadap Penggunaan Sistem Financial Technology. Jurnal MAPS (Manajemen Perbankan Syariah), 4(1):36-44

Bank Indonesia. (2013). Peredaran Data Uang Elekronik di Indonesia. Jakarta. Bank Indonesia 
Blaine, L.D. \& Britt, S.H. (2012). Measuring Advertising Effectiveness McGrawHill, New York.

Daryanto, D. \& Setiyabudi, I. (2014). Masalah Pencemaran. Bandung; Tarsito

Dharmestra, B.S. \& Irawan, (2008).Manajemen Pemasaran Modern. Yogyakarta: Liberty

Fatihudin, D., Mochklas, M., \& Suryati, D.A. (2019). The Effect of Brand Image Perception and Product Quality Toward the Interest to Buy Consumer Pre-Pay IM3 Ooredoo. 1st Borobudur International Symposium on Humanities, Economics and Social Sciences (BIS-HESS 2019), Advances in Social Science, Education and Humanities Research, volume 436 pp. 53-57

Febrilia, I., Pratiwi, S.P. \& Djatikusumo, I. (2020). Minat Penggunaan Cashless Payment System - Dompet Pada Mahasiswa Di FE UNJ. Jurnal Riset Manajemen Sains Indonesia (JRMSI), 11(1): 1-19

Huraerah, A. \& Purwanto. (2010). Dinamika Kelompok Konsep \& Aplikasi. Bandung : PT Refika Aditama

Immawati, S.A. \& Dadang. (2019). Minat Masyarakat Bertransaksi Menggunakan Financial Technology (Fintech)

Di Kota Tangerang. Prosiding Simposium Nasional Multidisiplin (SinaMu) LP3M Universitas Muhammadiyah Tangerang 2019

Jakni. (2016). Metodologi penelitian eksperimen bidang Pendidikan. Bandung: Alfabeta

Keller, K.L. (2013). Strategic Brand Management ; Building, Measuring, and Managing Brand Equity. Fourth Edition Harlow, English : Pearson Education Inc.

Kotler, P. \& Keller, K.L. (2013). Manajemen Pemasaran. Edisi 13 Jilid satu. Jakarta: Erlangga

Kurniawan, A. (2011). SPSS Serba-Serbi Analisis Statitistika Dengan Cepat Dan Mudah. Jakarta: Jasakom

Mochklas, M., \& Wibowo, T.S. (2018). Dasar-Dasar Manajemen Membangun Organisasi. Surabaya: TS. Publisher

Pambudi, R.D. (2019). Perkembangan Fintech Di Kalangan Mahasiswa UIN Walisongo. Harmony, 4 (2), 74-81

Parasuraman, V.A.(2011). A Conceptual Model of Service Quality and Its Implication forr Future Reaserch. Service Quality, 2015-220

Rangkuti, F. (2012). Studi Kelayakan Bisnis \& Investasi. Jakarta: Gramedia Pustaka Utama

Ravikawati, C., Fatihudin, D., \& Mochklas, M. (2019). Pengaruh Harga, Citra Merek, Dan Word Of Mouth Terhadap Keputusan Pembelian Di Toko Buku Gramedia Surabaya Expo. Jurnal EKSEKUTIF, 16(1): 6379

Rofi'I, N.A., Mochklas, M.,\&Mochklas, M. (2019). Pengaruh Strategi Bauran Pemasaran Terhadap Peningkatan Penjualan Pada Produk Dr. Kebab Bara Satriya Sidoarjo. Balance, 16(1): 112-119

Sugiyono. (2009). Metode Penelitian Kuantitatif Kualitatif dan R\&D. Bandung : Alfabeta

Sunyoto, D. (2012). Dasar-dasar manajemen pemasaran. Cetakan Pertama. Yogyakarta: PT.Buku Heru

Thamrin, A. \& Francis, T. (2012). Manajemen Pemasaran. Jakarta : PT Raja Grafindo Persada.

Tjiptono, F. (2011). Service Management Mewujudkan Layanan Prima. Edisi 2. Yogyakarta: Andi

Tjiptono, F. (2014), Pemasaran Jasa: Prinsip, Penerapan, dan Penelitian. Yogyakarta: Andi Offset 